\title{
Comparative Analysis of Direct Labour and Contracting System of Project Procurement
}

\author{
Nwokenkwo Ben Chinedum ${ }^{1}$,Yunusa Dauda ${ }^{2} \&$ Faruk, Abubakar Isah ${ }^{3}$ \\ ${ }^{1,2,3}$ Department of Estate Management, Federal Polytechnic Bida, Niger State, Nigeria \\ Abstract \\ This study examines the performance of two project procurement methods commonly used in project construction, \\ the direct labour and contracting system. Using cost, time and quality as assessment criteria, the work seek to \\ determine possible advantage of one method over the other. Quasi-experimental design and questionnaire were \\ combined to carry this study. Respondents was mainly officers and building contractors, key players in project \\ procurement. Results obtained in this work showed that there was no significant difference between the two \\ methods in terms of cost overrun, though overall cost was higher for the direct labour method. It also revealed a \\ significant difference between time overrun for the two methods as direct method took longer time. The study \\ concluded by emphasising the need for training, openness and empowerment. It also recommended the need for \\ all establishments to adopt participatory project management through direct labour.
}

Key Words: Direct Labour, Contract, Procurement, Time, Cost, Cost overrun, Time overrun

DOI: $10.7176 /$ CER/11-8-07

Publication date:September $30^{\text {th }} 2019$

\subsection{Introduction}

Direct labour system is one of the several options of procurement used for project delivery process and, records has shown that it is the oldest procurement system that has been in use far back as the colonial era. In Nigeria, the direct labour system dates back to the pre-colonial era. During this period, building construction was a collective effort of the community. When a person decides to erect a building, he would inform his clan's men and they would first erect the frame structure with pitched thatched roof, excavate the foundation after which he hires labour to erect mud walls till completion.

It is very prominent in most countries and researchers described it as a system whereby a developer plans and organizes the project delivery process, carries out the design, the planning and procurement of resources and the construction of a project using client employed supervisory staff and labour. Within this period, building construction remained a direct negotiation between the client and the various craftsmen and labourers responsible for the construction of the work. This system is regarded as in-house because client's staff are different from contractor's staff that carry out the project delivery process and activities.

The execution of works by direct labour system in Nigeria remained in its infancy till $18^{\text {th }}$ century when it received a boost from the colonial masters, when the building pattern that was obtainable in United Kingdom and its attendant practices was imported into Nigeria. This led to the establishment of the public works department now the ministry of works, charged with the construction and maintenance of civil engineering works such as local bridges, culverts, roads and public building works of less complex nature in laison with the municipal councils, now local government authorities. Idoro et al., (2007) asserted that direct labour is mainly used for government projects. The use of the system is a good development in construction because it does not result in high staff strength and overhead costs in the Nigerian construction industry.

The contractual system was inevitably carried out in pari-pasu with the direct labour system with the later used for simple projects. This was due to the nation's quest for development which called for more sophisticated and complex projects. This dual system of execution of works continued till the nation's independence in 1960 when Nigeria embarked on expansionist development programmes which led to the re-introduction of more complex projects in terms of infrastructures as a mark of the nation's development programme, the re-building programme after the Nigerian civil war also added to the need for contractual system. Thus the need for rapid national development gave contractual system a big boost and edge over the direct labour system, though the direct labour system was not completely abandoned. The term procurement system refers to a project execution and delivery process and it describes the responsibilities and/ or contractual obligations of the parties to carry out the numerous activities involved in delivering a project to the owner. According to Ojo (2009), procurement involves the various combination of the design and construction phase to achieve the forms of organization to implement the 
project.Maizon (2003) mentioned that the selection of a procurement method for a given project is a difficult task for the clients due to the various factors governing a construction project. Maizon (2003)stated further that different client have differing needs and requirements whereby construction projects vary so considerably and in every respect, that no single method of procurement can be suitable for every project. This method of execution of project by direct labour manifests itself again both at the as a means of conserving costs expended through contractual system or for more effective utilization of the professionals gainfully employed.

Time and cost overrun have been a major problem confronting the Nigerian construction industry. Problems that have been established from various research work that have been carried out in past as result of the use of direct labour in execution of construction projects includes high staff strength, time and cost overrun, poor quality delivery e.t.c

These problems of direct labour and other procurement method adopted in Nigerian construction industry have raises serious concern to the project stakeholders and the construction industry as a whole. The problem of government projects execution has led to a situation whereby the dream of the Clients (the government) has been shattered. Some private sponsors of projects too have suffered the same fate in realizing that their investments in projects have turned futile. The budgeted cost always over run and the performance in terms of quality and workmanship are not up to expectation. At times the projects are abandoned altogether before completion, among other common symptoms. In view of the problems associated with the execution of projects by traditional method of procurement, the large amount of money expended on them and their remarkable and indispensable contribution to the economic growth of the nation, it is highly imperative to examine thoroughly the viability of participatory project management by direct labour method.

Masterman (1996) described project procurement as the organizational structure needed to design and build construction projects for a specific client. It is in a sense very true because the process of "obtaining" a building by a client involves a group of people who are brought together and organized systematically in term of their roles, duties, responsibilities and interrelationship between them. On the other hand, the direct labour approach is where the client uses his or her in-house human resources to carry out a construction project. Opadiran (1987) defined it as a process by which a project is executed by the workers of an organisation instead of the project being contracted out. It can simply be described as a do it yourself' approach to project procurement.

\subsection{Literature Review}

The CIB (1997a) suggests developing a strategy for the project on the basis of the client's need and that the first priority is to decide how to procure skills and resources needed for the design and construction of the project. Turner (1997) suggests that an appropriate procurement method route will develop from an understanding of the objectives and priorities of the client and that a number of procurement assessment criteria needs to be considered.Mojekwu (1998), El Rufai (1992), Ogunsanmi and Bamisile (1997) identified five methods of project procurement commonly used in Nigeria as: the traditional method; the direct labour method; labour only method; management contracting method and design and build method. Kettle (1976) identified several advantages inherent in this method of project procurement. Grifith (1965) documented some of the limitations with the traditional method. In addition, Males and Stock (1985) found that over-emphasis on contractual arrangements rather than an effective organisational problem was the main set- back of the traditional method of project procurement. Iyagba and Idoro (1995) has given some of the advantages of the direct labour method. Ogunsanmi et al., (1995) however concluded among many others that directly employed labour eases the problem of communication and enhances better working relations and the control of quality. According to Odulani (1996) in Adeniji (2011), the chief reason for using the direct labour system as against contract system are the realization of savings in cost and time with assurance of high quality. Iyagba and Idoro (1995), direct labour method of procurement includes fully Inhouse direct labour, partially In-house, hire-labour direct labour, and self-help type of direct labour. Olufelo (1988) and Wahap (1983) in Adeniji (2011) highlighted several reasons for re-emergence of the direct labour system. Fagbenle (1999) noted that there may be a shoddy attitude to work at times on the part of the operatives.According to Odulami (1996) as quoted by Adeniji (2011), the chief reason for using the direct labour system as against contract system are the realization of savings in cost and time withassurance of high quality. Bello and Agbatekwe (2002) noted that, since this method direct labour method does not involve any contractor in the case of a building project, the required production informtion and bills of quantities may be simplified. Bello and Agbatekwe (2002) also sugests that direct labour method may be unsuitable for large projects because organisations may not have the ultimate capacity or lack sufficient plants or machinery including skilled staff to sufficiently execute the project. 


\subsection{Methodology}

Questionnaire were distributed to identified respondents who filled and returned the questionnaire. Responses were analysed using table of frequencies and percentages.

\subsubsection{Results and Discussion}

Table 3.1: Professional Discipline

\begin{tabular}{lcc}
\hline Professional & Frequency & Percentage (\%) \\
\hline Architecture & 3 & 10.0 \\
Engineering & 17 & 56.7 \\
Building & 7 & 23.3 \\
E/Surveying & 2 & 6.7 \\
Town Planning & 1 & 3.3 \\
\hline Total & $\mathbf{3 0}$ & $\mathbf{1 0 0}$ \\
\hline
\end{tabular}

Source: Field Survey (2018)

From table 3.1, majority of the respondents are Engineers with highest percentage of $56.7 \%$ followed by the Architects. The result could be attributed to the fact that the Architects and the Engineers have been in the construction practice before other professionals in the built environment.

Table 3.2: Category of Project

\begin{tabular}{ccc}
\hline Category & Frequency & Percentage (\%) \\
\hline New & 10 & 33.3 \\
Renovation & 20 & 66.7 \\
\hline Total & $\mathbf{3 0}$ & $\mathbf{1 0 0}$
\end{tabular}

Source: Author's Field work 2018

Table 3.2 indicated the category of projects considered for the study but only Ten (10) of these projects consisting of five new projects and five renovation works were thus selected for each of the two procurement methods for comparison.

Table 3.3: Projects Procured by Traditional Contract Method

\begin{tabular}{lllllll}
\hline Project & Initial Cost & Final Cost & $\begin{array}{l}\text { Cost } \\
\text { Overrun }\end{array}$ & Initial Time & Final Time & $\begin{array}{l}\text { Time } \\
\text { Overrun }\end{array}$ \\
\hline R1 & 1.80 & 2.10 & 0.30 & 2 & 3 & 1 \\
R2 & 1.80 & 1.90 & 0.10 & 2 & 4 & 2 \\
R3 & 2.10 & 2.40 & 0.30 & 3 & 5 & 2 \\
R4 & 2.10 & 2.10 & 0.00 & 3 & 3 & 0 \\
R5 & 4.50 & 4.90 & 0.40 & 10 & 12 & 2 \\
N6 & 3.20 & 3.60 & 0.40 & 4 & 6 & 2 \\
N7 & 6.80 & 7.50 & 0.70 & 12 & 14 & 2 \\
N8 & 30.00 & 36.50 & 6.50 & 22 & 24 & 2 \\
N9 & 30.00 & 36.50 & 6.50 & 22 & 24 & 2 \\
N10 & 30.00 & 36.50 & 6.50 & 22 & 25 & 3 \\
\hline
\end{tabular}

Source: Field Survey (2018).Hint: $\mathrm{R}=$ Renovation. $\mathrm{N}=$ New construction

Table 3.3 shows the cost and time overruns of renovation and new construction works procured by traditional contract method reflecting their unit costs. 
Table 3.4: Projects Procured by Direct Labour Method

\begin{tabular}{lllllll}
\hline Project & Initial Cost & Final Cost & $\begin{array}{l}\text { Cost } \\
\text { Overrun }\end{array}$ & Initial Time & Final Time & $\begin{array}{l}\text { Time } \\
\text { Overrun }\end{array}$ \\
\hline R1 & 1.10 & 1.10 & 0.00 & 2 & 3 & 1 \\
R2 & 1.20 & 1.30 & 0.20 & 2 & 4 & 2 \\
R3 & 1.50 & 1.50 & 0.00 & 3 & 4 & 1 \\
R4 & 1.50 & 1.70 & 0.20 & 3 & 3 & 0 \\
R5 & 3.20 & 3.50 & 0.30 & 12 & 14 & 2 \\
N6 & 2.10 & 2.40 & 0.30 & 6 & 8 & 2 \\
N7 & 4.50 & 5.10 & 0.60 & 12 & 15 & 3 \\
N8 & 20.00 & 25.00 & 5.0 & 24 & 27 & 3 \\
N9 & 20.00 & 25.00 & 5.0 & 24 & 26 & 2 \\
N10 & 20.00 & 25.00 & 5.50 & 24 & 26 & 3 \\
\hline
\end{tabular}

Source: Author's Fieldwork, 2018

Table 3.4 shows the cost and time overruns of renovation and new construction works procured by direct labour method

Table 3.5: Ranking of Likely Causes of Cost Overrun (Traditional \& Direct Labour)

\begin{tabular}{lcccccc}
\hline Likely causes of cost overrun & $\begin{array}{c}\text { Most } \\
\text { likely }\end{array}$ & Likely & Undecided & $\begin{array}{c}\text { Not } \\
\text { likely }\end{array}$ & $\begin{array}{c}\text { Most } \\
\text { likely }\end{array}$ & $\begin{array}{c}\text { Overall } \\
\text { Ranking }\end{array}$ \\
\hline Lack of proper coordination & 3 & 6 & 3 & 16 & 2 & 1 \\
Lack of adequate control & 2 & 9 & 0 & 13 & 6 & 2 \\
$\begin{array}{l}\text { Changes in scope and quality of } \\
\text { work }\end{array}$ & 3 & 4 & 1 & 9 & 13 & 3 \\
Lack of adequate planning & 4 & 2 & 0 & 10 & 14 & 4 \\
\hline
\end{tabular}

From the analysis, the predominant factors are; lack of proper coordination and adequate control. Other factors are the changes in scope and quality of work most especially by the clients and lack of adequate planning.

Table 3.6:Ranking of likely causes of time overrun (Traditional \& Direct Labour)

\begin{tabular}{lcccccc}
\hline Likely causes of cost overrun & $\begin{array}{c}\text { Most } \\
\text { likely }\end{array}$ & Likely & Undecided & $\begin{array}{c}\text { Not } \\
\text { likely }\end{array}$ & $\begin{array}{c}\text { Most } \\
\text { likely }\end{array}$ & $\begin{array}{c}\text { Overall } \\
\text { Ranking }\end{array}$ \\
\hline Failure to order materials & 20 & 3 & 1 & 3 & 3 & 1 \\
Subcontractor/supplier delay & 11 & 10 & 0 & 3 & 6 & 2 \\
Lack of requisite equipment & 3 & 9 & 0 & 8 & 10 & 3 \\
Attitude of construction workers & 1 & 2 & 2 & 19 & 6 & 4 \\
Inadequate labour force & 1 & 2 & 0 & 19 & 8 & 5 \\
Poor motivation of workforce & 2 & 3 & 0 & 10 & 15 & 6 \\
Inadequate design information & 3 & 1 & 0 & 7 & 19 & 7 \\
\hline
\end{tabular}

Table 3.6 revealed the likely factors causing time overrun in traditional and direct labour methods of procurement. From the analysis, the most prominent factors are; failure to order materials as scheduled, delay due to subcontractor and suppliers assignments and lack of requisite equipment to cope with project demand. Other reasons are negative attitude of construction workers, inadequate labour force, poor motivation of workforce and delay due to inadequate design information.

The result of the analysis of time overrun in direct labour was similar to the result of a survey conducted by Odusami and Olusanya (2000) which discovered the average time overrun on projects to be $51 \%$. However, the result is higher than the result of another study by Idoro (2007) which discovered that average delay was $25 \%$. This finding indicates that time overrun is a common feature of projects procured by the two systems. However, projects procured by direct labour system are prone to higher time overrun than those procured by traditional method. Another major findings confirmed in this study is that cost overrun is a feature of the two procurement systems especially for large projects. The implication of this finding is that contingency sum is set aside for the purpose of additional cost. It costs more to execute a project using the traditional method than employing the direct labour option for the same project. This result agrees with the result of a study conducted by Odusami (2001). 
The results also indicate that there is no significant difference between the two methods in their conformity with specifications standard of workmanship and satisfaction with the quality of materials. The unit cost of projects procured using the traditional method is higher than the unit cost of similar projects procured using the direct labour method. This finding agrees with the position of the Federal Government of Nigeria on the adoption of direct labour system (Federal Military Government, 1986). Security implication was one of the main reasons proffered by respondents for choosing the direct labour method. Time overrun as experienced is not due to a lack of adequate planning but due largely to a lack of adequate equipment and likely delay due to subcontractor/supplier's work.

Table 3.7: Precision Levels or Margin of Error of Some Selected Variables

\begin{tabular}{|l|l|l|l|}
\hline S/No & Variables & $\begin{array}{l}\text { No. Of } \\
\text { Respondents }\end{array}$ & $\begin{array}{l}\text { Margin of } \\
\text { Errors \% }\end{array}$ \\
\hline 1 & Have you ever been involved in the execution of any project & 39 & 2 \\
\hline 2 & Did you directly participate in the project & 42 & 2 \\
\hline 3 & Is the project cost effective & 41 & 2 \\
\hline 4 & Has the project's life cycle been completed & 35 & 4 \\
\hline 5 & Was it completed within the stipulated time frame & 36 & 3 \\
\hline 6 & Is the project still in existence & 34 & 5 \\
\hline 7 & Do you believe the project has met its intended objective & 45 & 2 \\
\hline
\end{tabular}

This indicates that the precision of the obtained survey result is high.

For example about seventy percentage of the respondents reported that they participated in project execution in their ministries with plus or minus $2 \%$ margin of error at $95 \%$ level of confidence. This term simply means that if the survey were conducted 100 times, the percentage who say 'they participated in project execution in their ministries will range between 68 and $72 \%$ most (95\%) of the time.

\subsection{Conclusions}

This research work has provided a good appreciation of the roles that direct labour and traditional procurement systems have played in the developmental programmes of Nigeria. The results enable prospective developers to appreciate the strengths and weaknesses of direct labour and traditional procurement systems. It has been observed that most clients in Nigeria use the two procurement systems and the task they often face is how to select the appropriate system for a project. Based on this understanding, the study has developed basic facts of procurement choice for prospective developers. The findings also provide bases for proper management of project delivery process when both procurement systems are used. Further exposure and training of the in-house staff of the Nigerian Army would lead to a reduction of time for the execution of direct labour projects, and indeed enhance quality and save cost. Having discussed various implications of the result of this work, it is recommend amongst many others that, for direct labour to thrive,

i. The employer should have sufficient work to keep the staff busy every year.

ii. Should have the professional to conceive, design, estimate, execute, monitor and commission the project

iii. There should be availability of relevant plant and equipment

iv. Facilities for checking waste, over-invoicing, pilfering, should be made available

v. Efficient and honest in-house audition and supervision is necessary. It is adviceable to set up these direct labour groups as self-accounting units so that they can be put in competition with profit oriented contracting organization. This will result in competitive standard of workmanship, delivery time and final cost of project.

vi. The Civil Service ethics where the government work is termed 'no man's work' must be stopped and spirit of nationalism and patriotism injected into the civil service. This could be achieved by operating some incentive scheme eg bonus sharing

vii. Performance should be made a yardstick for promotions and allocation of amenities to the officials. 


\section{REFERENCES}

Adeniyi, E.O, (2002), "Managing Government Projects by Direct Labour: A Case Study of Adamawa State Direct Labour Task force" MPM Thesis submitted to School of Postgraduate Studies, University of Lagos, Akoka, Yaba - Lagos

Adeniji, E.O (2011), The Significance of Participatory Management on Project Execution Through Direct Labour: A Case Study of Adamawa State Nigeria. PhD Dissertation, St. Clement University, British West Inies

Bello M.A, Agbatekwe A.C (2002), Project Management in Property Development. The NigerianExperience. Ibadan: University Press, Ibadan.

E1-Rufai, E.N. (1992), An overview of the Generic types of Contractual Arrangement, Paper presented at the Conference on Management Contracting in Nigeria.

Fagbenle, O. (1999), "Direct labour system in a depressed economy", NIOB seminar paper. Obafemi Awolowo University, Nigeria.

Federal Government of Nigeria (1986) Budget of the Federal Republic of Nigeria, Federal Government Press, Lagos, Nigeria.

Griffith, A. (1985), ‘An unpublished lecture note on “Construction Management”, Department of Building, Herriot Watt University, Edinburgh, Scotland.

Idoro, G.I. (2007) A Comparative study of direct labour and design-tender-Construct Procurement Systems in Nigeria. P.hD. Thesis Department of Building, University of Lagos, Akoka, Yaba, Lagos, Nigeria.

Idoro, G.I, Iyagba, R.O.A and Odusami J (2007): Client Characteristics and the Use of Direct Labour in The Nigerian Construction Industry: In Proceedings of RICS Construction and Building Research Conference (COBRA, 2007), 5 - 7 Sept. Georgia Institute of Technology, Atlanta Georgia

Iyagba, R and Idoro G. I. (1995), “An Overview of Direct Labour Construction in the Declining Economy of Nigeria”, Construction in Nigeria , 4, 2-13.

Kettle, K.A (1976), "Project Delivery System for Construction Projects”, Journal of the Construction Division of ASCE, 576.

Males, S.P and Stock, A. (1985), An Investigation into Chart Perception of Contractual Forms and Procedures, Department Of Building, Heriot Watt University, Edinburgh, Scotland.

Masterman, J.W.E (1996): Building Procurement Systems: An Introduction. London: E\& FN Spon

Mojekwu, C.K.S. (1998) Procurement Methods in Construction Projects. A seminar paper presented at the Department of Building, University of Lagos, Akoka, Yaba, Lagos, Nigeria.

Ndagi, J (1984): The Essentials of Research Methodology for Nigerian Educators. Ibadan: University Press Ltd

Odusami K.T. (1999) Comparative study of Nigerian and Ghanaian Construction Industry, Construction in Nigeria 14(2)15-28.

Odusami, K.T and Olusanya (2000) client's contribution to Delays on Building Projects. The Quantity Surveyor, October - December, Vol 26.

Odusami, K.T. (2001) Project Team Leadership and Construction Project Performance in some selected States in Nigeria. P.hD Thesis. Department of Building, University of Lagos, Akoka, Yaba, Lagos, Nigeria.

Ogunsanmi, O.E. and Bamisile, A. (1997), 'Factors Affecting the Selection of Project Procurement Methods", Builders Magazine , 7(2), 
Ogunsanmi, O.E, lyagba, R.O.A and Omirin, M.M. (2001), "Modeling procurement performance in housing projects in Nigeria", The Lagos Journal of Environmental Studies. 3(1), 16- 35.

Ojo, S.O (2009): Benchmarking the Performance of Construction Procurement Methods Against Selection Criteria in Nigeria. Civil Engineering Dimension 11 (2) pp 106 - 112

Omotosho, S.T. (1999) Management of Labour Only Contract for Building Construction Projects in Lagos Metropolis. M.Sc Thesis, Department of Building, University of Lagos, Akoka, Yaba, Lagos, Nigeria

Opadiran, J. K. (1987), “Use of Direct Labour in Programme Execution”, seminar paper, Economic and Financial Studies Department ASCON, Topo, Badagry.

Ramus J.M (1980): Contract Practice for Quantity Surveying. Heinemann London $1^{\text {st }}$ ed.

Turner, A (1997): Building Procurement. Palgrave UK: Macmillan Ltd 